\title{
DANUTA BOROS
}

\section{DAMIAN GOLEB IEWSKI}

Instytut Hodowli i Aklimatyzacji Roślin — Państwowy Instytut Badawczy, Radzików, Samodzielna

Pracownia Oceny Jakości Produktów Roślinnych

Kierownik Tematu: prof. dr hab. Danuta Boros Samodzielna Pracownia Oceny Jakości Produktów

Roślinnych, Instytut Hodowli i Aklimatyzacji Roślin - Państwowy Instytut Badawczy, Radzików, 05-870 Błonie, tel. +48 (22) 7334547, e-mail: d.boros@ihar.edu.pl

Prace zostały wykonane $w$ ramach badań podstawowych na rzecz postępu biologicznego w produkcji roślinnej na podstawie decyzji Ministra Rolnictwa i Rozwoju Wsi nr HOR.hn.802.19.2018 Zadanie 32.

\section{Badanie składników determinujących wartość odżywczą i funkcjonalną owsa oraz ich relacji w ziarnie obłuszczonym i oplewionym}

\section{Components determining the nutritive and functional values of oat and its relation between hulled and dehulled grains}

Słowa kluczowe: metody selekcji, owies, wartości prozdrowotne, wartość żywieniowa, zmienność genotypowa

\section{CEL BADAŃ}

Celem badań prowadzonych w latach 2014-2018 było opracowanie współczynników konwersji umożliwiających charakterystykę składu chemicznego ziarna obłuszczonego na postawie składu ziarna oplewionego, niezbędnych do szybkiego wyodrębniania genotypów owsa najbardziej przydatnych do produkcji żywności funkcjonalnej. W ramach zadania opracowano również warunki pomiaru lepkości, jako prostego testu przesiewowego do zastosowania $\mathrm{w}$ pracach hodowlanych nad tworzeniem genotypów owsa o wysokiej wartości prozdrowotnej bądź paszowej.

\section{WYNIKI}

W okresie pięciu lat badań analizowano ogółem 203 próbki owsa, w formie oplewionej i po ich obłuszczeniu. Stwierdzono małe zróżnicowanie zawartości składników odżywczych ogółem w ziarnie oplewionym badanych odmian i linii owsa, zmienność tej cechy była na poziomie 5,2\%, a średnia zawartość wynosiła $64 \%$ (tab. 1). 
Zmienność zawartości składników odżywczych w ziarnie owsa oplewionym i obłuszczonym ze zbioru w latach 2013-2017 (\% s.m.)

\begin{tabular}{|c|c|c|c|c|c|c|}
\hline & Białko & $\begin{array}{l}\text { Składniki } \\
\text { mineralne }\end{array}$ & Lipidy & Skrobia & Cukry wolne & $\mathrm{SSO}$ \\
\hline \multicolumn{7}{|c|}{ Ziarno oplewione } \\
\hline Wartość średnia & 11,4 & 2,7 & 5,6 & 42,4 & 1,5 & 63,7 \\
\hline$s d$ & 1,7 & 0,3 & 0,7 & 3,2 & 0,2 & 3,3 \\
\hline $\mathrm{CV}$ & 14,9 & 11,1 & 12,8 & 7,5 & 16,1 & 5,2 \\
\hline $\min$. & 6,6 & 2,1 & 4,3 & 30,6 & 1,0 & 54,7 \\
\hline $\max$ & 17,1 & 3,4 & 7,6 & 48,9 & 2,2 & 72,0 \\
\hline \multicolumn{7}{|c|}{ Ziarno obłuszczone } \\
\hline Wartość średnia & 14,8 & 2,2 & 7,6 & 56,1 & 1,7 & 82,0 \\
\hline$s d$ & 1,9 & 0,1 & 1,4 & 2,9 & 0,2 & 2,4 \\
\hline $\mathrm{CV}$ & 13,1 & 5,9 & 18,2 & 5,2 & 14,6 & 2,9 \\
\hline $\min$. & 10,3 & 1,8 & 5,1 & 45,1 & 1,1 & 73,9 \\
\hline $\max$. & 19,4 & 2,5 & 11,8 & 61,4 & 2,8 & 87,6 \\
\hline
\end{tabular}

Największym zróżnicowaniem charakteryzowała się zawartość cukrów wolnych (16,1\%), następnie białka $(14,9 \%)$, lipidów $(12,8 \%)$ oraz popiołu $(11,1 \%)$, a w najmniejszym stopniu skrobi $(7,5 \%)$. Zawartość trzech ostatnich składników odżywczych określono jako stabilną w warunkach uzyskania ziarna, a zmienność wartości tych parametrów była wynikiem w głównej mierze zmienności genetycznej. Owies charakteryzował się dużą zawartością błonnika pokarmowego (TDF), średnio w ziarnie było 32,3\%, przy zmienności około $10 \%$ (tab. 2).

Tabela 2

Zmienność zwartości składników bioaktywnych w ziarnie owsa oplewionym i obłuszczonym ze zbioru w latach 2013-2017 (\% s.m.)

\begin{tabular}{|c|c|c|c|c|c|c|c|c|c|}
\hline & I-NSP & S-NSP & T-NSP & Lignina Klasona & TDF & $\beta$-glukan & I-AX & S-AX & $\mathrm{AX}$ \\
\hline \multicolumn{10}{|c|}{ Ziarno oplewione } \\
\hline Wartość średnia & 18,5 & 3,5 & 22,1 & 10,3 & 32,3 & 3,1 & 8,9 & 0,3 & 9,1 \\
\hline$s d$ & 2,5 & 0,5 & 2,5 & 1,3 & 3,2 & 0,4 & 1,2 & 0,0 & 1,2 \\
\hline $\mathrm{CV}$ & 13,5 & 13,2 & 11,1 & 12,9 & 9,8 & 13,2 & 13,5 & 15,0 & 13,1 \\
\hline min. & 12,6 & 2,5 & 16,4 & 6,6 & 24,1 & 2,3 & 5,7 & 0,2 & 6,0 \\
\hline $\max$ & 25,0 & 4,8 & 28,5 & 14,5 & 41,0 & 4,6 & 12,0 & 0,5 & 12,3 \\
\hline \multicolumn{10}{|c|}{ Ziarno obłuszczone } \\
\hline Wartość średnia & 4,1 & 4,7 & 8,8 & 4,0 & 12,7 & 4,1 & 2,0 & 0,3 & 2,3 \\
\hline$s d$ & 0,5 & 0,5 & 0,8 & 1,3 & 1,8 & 0,5 & 0,2 & 0,0 & 0,2 \\
\hline $\mathrm{CV}$ & 11,6 & 11,8 & 9,1 & 31,8 & 13,9 & 11,7 & 11,5 & 11,4 & 10,3 \\
\hline min. & 2,3 & 3,3 & 6,1 & 1,2 & 8,3 & 2,9 & 1,1 & 0,2 & 1,3 \\
\hline $\max$. & 5,2 & 6,2 & 10,7 & 7,3 & 16,9 & 5,9 & 2,6 & 0,4 & 2,9 \\
\hline
\end{tabular}

Wśród składników błonnika pokarmowego największy w nim udział stanowiła frakcja nierozpuszczalna nieskrobiowych polisacharydów (NSP) (57\%) oraz lignina (32\%). $\beta$-glukan, składnik w największym stopniu odpowiedzialny za prozdrowotne właściwości owsa, stanowił blisko 10\% TDF z zawartością średnio 3,1\% i zmiennością 13\%. Plewka stanowiła średnio około $26 \%$ masy ziarniaka, a jej udział wpływał istotnie na zawartość składników odżywczych i bioaktywnych w ziarnie owsa, w każdym roku badań. Ze wzrostem jej udziału malała ilość białka, skrobi i lipidów, a także rozpuszczalnych 
składników NSP. Wzrastała natomiast zawartość frakcji nierozpuszczalnej NSP i ligniny, a przez to TDF.

\section{WNIOSKI}

1. Usunięcie plewki miało wpływ na zwiększenie zawartości tych składników, które sa zlokalizowane $\mathrm{w}$ endospermie oraz zarodku ziarna owsa. W takim ziarnie zawartość składników odżywczych zwiększyła się średnio o $29 \%$. Zmniejszyła się zawartość nierozpuszczalnej frakcji NSP (78\%), a w następstwie zawartość TDF, do poziomu około 13\%. Spośród składników błonnika pokarmowego w ziarnie obłuszczonym zwiększyła się jedynie zawartość frakcji rozpuszczalnej NSP (o 32\%), a w szczególności $\beta$-glukanu (o 30\%).

2. Na podstawie wyników pięcioletnich badań obliczono współczynniki korelacji Pearsona i regresji liniowej pomiędzy ziarnem oplewionym i po jego obłuszczeniu w odniesieniu do każdego oznaczanego składnika. Największym odwzorowaniem z wykorzystaniem współczynników regresji liniowej charakteryzują się: zawartość białka, lipidów i MTZ.

3. W pracach metodycznych nad udoskonaleniem testu lepkości ziarna obłuszczonego i oplewionego przeznaczonego odpowiednio do produkcji żywności bądź na paszę wyznaczono najbardziej odpowiednie dla ziarna owsa warunki ekstrakcji oraz wskazano czynniki w największym stopniu wpływające na lepkość. 
